\title{
Unpacking the Liberal Peace: The Dividing and Merging of Peacebuilding Discourses
}

John Heathershaw ${ }^{1}$

This paper assesses the discursive environment of post-conflict intervention as a prism through which to view the international politics of the post-Cold War era. I argue that the 'liberal peace' is not a single discourse but a tri-partite international discursive environment that dynamically reproduces technical solutions which fail to address the core issues of conflict in a given place. The paper starts from the assumption that over the last twenty years we have seen a shift from an understanding of peace as a state of affairs in a given territory (as explored by Michael Banks in a 1987 paper) to peace as a process of post-conflict intervention; a move from peace to peacebuilding. This 'liberal peace' sets a standard by which 'failed states' and 'bad civil societies' are judged according to ethical, spatial and temporal markers. However, the apparent homogeneity of the model obscures the divisions and mergers which characterise the scholarship and practice of international peacebuilding. The boundaries of the peace debate remain; the political differences latent in Banks' three concepts are retained in the evolving discourses of democratic peacebuilding, civil society and statebuilding. The paper shows how these three basic discourses are reproduced in international policy analyses and major academic works. Moreover, the discursive mediation of their differences is the dynamic by which the liberal peace is sustained, despite its detachment from the lived experiences of post-conflict environments. It is in this sense that we can comprehend international peacebuilding as a virtual phenomenon, maintained in the verbal and visual representations of international organisations, diplomats and academic policy-practitioners. In light of this disaggregation of the discursive environment, a better, more nuanced understand of the liberal peace can be attained; one that is able to grasp how critics and criticisms become incorporated into that which they seek to critique. The paper concludes with three propositions regarding the nature of world order in the era of the tripartite 'liberal peace'. During this time coercion, military force and even warfare have become standard and legitimate features of peacefare. The discursive dynamics of international peacebuilding illustrate how peace has become ever more elusive in contemporary international politics.

\section{Introduction}

The concept of peace was central to the early inquiries of International Relations yet in the Cold War era it was pushed to the margins of the discipline. Michael Banks' 1987 tripartite rendition of the concept of peace in international conflict resolution ${ }^{2}-$ as

${ }^{1}$ This article benefited from the comments and criticisms of numerous colleagues, in particular John Darby, Mark Hoffman, Michael Pugh, Oliver Richmond, Peter Wallensteen, two anonymous reviewers and the editors of Milliennium. However, any shortcomings are solely the responsibility of the author.

${ }^{2}$ In fact Banks' paper outlined four concepts including peace as harmony. This fourth approach is dismissed by Banks himself, and has been excluded here, as it does not characterise any approaches to peacebuilding within the international community. Michael Banks, 'Four Conceptions of Peace', in Conflict management and problem solving : interpersonal to international applications, eds Denis J. D. Sandole and Ingrid Sandole-Staroste. (London: F. 
conflict management, as order, and as justice - illustrated shortcomings in the theorisation of each of these concepts which largely remain today, despite some promising recent works. ${ }^{3}$ This paper uses discourses of post-conflict intervention as a prism through which to view this process of change in international politics. It reexamines international peacebuilding as found in the global spaces of the 'international community $^{\prime 4}$ - an emerging identity-group for the management of post-colonial and post-conflict spaces in world politics. Yet rather than assess world order in terms of a singular 'liberal peace', I provide an analysis of how such order is dynamically produced and reproduced in the inter-textual relations between three discourses of peacebuilding ${ }^{5}$ which echo Banks' three concepts of peace.

The paper is divided into three parts. Part one introduces the basic discourse of democratic peacebuilding which was developed by the United Nations, major donors and analysts in the immediate post-Cold War period. It shows how it is not just a form of praxis but represents peacebuilding as a process of post-conflict democratisation. In part two, I position this basic discourse in what I characterise as a tripartite discursive environment of peacebuilding and chart its similarities and differences with Banks' peace framework. Part three considers its two contending siblings, civil society (ascendant from the mid-1990s) and statebuilding (ascendant post-9/11), and shows how they divide from democratic peacebuilding in contemporary international debates. The fourth part illustrates how contending representations merge into a dominant metanarrative, pragmatic peacebuilding, which generates international intervention for virtual world order.

\section{A Unified Liberal Peacebuilding?}

Peacebuilding is an over-worked yet under-developed idea. Despite being used to mobilise significant political and economic resources for increasingly intrusive thirdparty interventions, peacebuilding is apparently little more than a composite of neoliberal problem-solving strategies - a form of praxis rather than a theory or concept. Whilst Lund argues that a unified understanding has emerged which constitutes 'an overarching multidimensional concept of peacebuilding, ${ }^{6}$ its practice, he acknowledges, remains 'a huge, hopeful experiment whose results are not clear'. Much verbiage is expended in an attempt to define it in sufficient breadth. ${ }^{8}$ Yet definitions remain vague. Ball, for example, remarks that peacebuilding 'requires that conflict resolution and consensus-building shape all interactions among citizens and

Pinter, 1987), 259-274.

${ }^{3}$ Oliver Richmond, The Transformation of Peace, (Basingstoke: Palgrave, 2005); MacGinty, Roger, No War, No Peace, (Basingstoke: Palgrave-MacMillan 2006).

${ }^{4}$ Hereafter the idea of 'international community' will be capitalised to International Community to convey its centrality as an identity signifier in peacebuilding discourse.

${ }^{5}$ I will continue to use 'peacebuilding' as a short hand for the discourses of international peacebuilding.

${ }^{6}$ Michael Lund, What Kind of Peace is Being Built? Taking Stock of Post-Conflict

Peacebuilding and Charting Future Directions, a paper for the International Development

Research Centre, Ottawa, Canada (January 2003), 13.

${ }^{7}$ Ibid, 16.

${ }^{8}$ For a wideners' perspective see Henning Haugerudbraaten, 'Peacebuilding: six dimensions and two concepts.' African Security Review 7, no.6 (1998), available from:

http://www.iss.co.za/ASR/7No6/Peacebuilding.html, accessed: 12 December 2004; for a reformist perspective see Lund, What Kind of Peace is Being Built?; for a radical perspective see, Alejandro Bendaña, What Kind of Peace is Being Built? Critical Assessments from the South, paper for the International Development Research Centre, Ottawa, Canada, Jan 2003. Available at: www.action.web.ca; accessed: 29 June 2004 
between citizens and the state'. ${ }^{9}$ Surveys of the literature often conclude with a restatement of fundamental questions about peacebuilding's practices and effects. ${ }^{10}$ I argue that the reasons for this inexactitude are not merely found in the aversion to rigorous conceptual analysis which is typical of policy-practitioners. A further problem is that no sooner had peacebuilding emerged as an international discourse than its proponents had begun to be challenged by advocates of alternative approaches to postconflict intervention.

The UN's 'post-conflict peacebuilding' emerged amid a reawakening of liberal internationalist ideals in the international community in the aftermath of the Cold War. Democratisation can be considered its discursive cousin, sharing peacebuilding's epistemological and ontological roots, and being hugely influential in its own right, informing international engagement with post-Soviet and post-colonial states. ${ }^{11}$ This link between peacebuilding, democratisation and even development is explicit in the policy literature. ${ }^{12}$ Boutros-Ghali was no less totalising in a 1993 speech:

Without peace there can be no development and there can be no democracy. Without development, the basis for democracy will be lacking and societies will tend to fall into conflict. And without democracy, no sustainable development will occur; without such development, peace cannot long be maintained. ${ }^{13}$

In this vein, peacebuilding texts reflect the holistic imaginary of this approach and have served to broaden its application across dimensions (from security to psycho-social) and deployments. Much of this literature is itself located within the liberal conflict management tradition ${ }^{14}$, and most clearly exhibited today in the work of Michael Doyle on the democratic peace 'between' states as well as peacebuilding 'within' them. ${ }^{15}$ Thus, the discourse of democratic peacebuilding presents a transition from war to peace with the elusive and illusory endpoint of a 'liberal democratic peace'. ${ }^{16}$

An ideologically-informed ethical stance lies at the heart of any policy discourse, perhaps especially one which is represented as pragmatic. In the case of democratic peacebuilding the ethics of liberal internationalism configured a particular

\footnotetext{
${ }^{9}$ Nicole Ball, 'The Reconstruction of War-Torn Societies and State Institutions: How Can External Actors Contribute?', in Fragile Peace: State Failure, Violence and Development in Crisis Regions, Ed. Tobias Debiel with Alex Klein, (London: Zed 2002), 37

${ }^{10}$ Michelle I. Gawerc, 'Peace-building: theoretical and concrete perspectives,' Peace and Change 31, no.4 (2006): 435-478.

${ }^{11}$ Samuel P. Huntington, The third wave: democratisation in the late twentieth century, (Norman: University of Oklahoma Press, 1991); Guillermo O’Donnell, and Philippe C. Schmitter, Transitions from authoritarian rule: tentative conclusions about uncertain democracies, (Baltimore: Johns Hopkins University Press, 1986); Adam Przeworski, Democracy and the market: political and economic reforms in Eastern Europe and Latin America, (Cambridge: Cambridge University Press, 19991).

${ }^{12}$ See, for example, Airat R. Aklaev, Democratisation and Ethnic Peace (Aldershot: Ashgate, 1999); Sunil Bastian and Robin Luckham, eds., Can Democracy be Designed? The Politics of Institutional Choice in Conflict Torn Societies (London: Zed Books, 2003); Tobias Debiel and Alex Klein, eds., Fragile Peace: State Failure, Violence, and Development in Crisis Regions (London: Zed 2002).

${ }^{13}$ Boutros Boutros-Ghali, Report on the work of the organisation from the forty-seventh to the forty-eight session of the general assembly (New York: United Nations, 1993), no pagination.

${ }^{14}$ Banks, 'Four Concepts of Peace', 271

${ }^{15}$ Michael W. Doyle, 'Liberalism in World Politics'. American Political Science Review 80, no. 4 (1986): 1151-69; Michael W. Doyle, and Nicholas Sambanis, Making War and Bulding Peace: United Nations Peace Operations, (Princeton: Princeton University Press, 2006).

${ }^{16}$ MacGinty, No War, No Peace.
} 
response to violent conflict. Developing in tandem with the first George Bush's hopes for 'new world order' and with Boutros-Ghali's aspirations to a stronger role for the United Nations, it was born amid the latter's Agenda for Peace (AfP) in 1992. The 'new interventionism' of the UN emerged from a sense of optimism engendered by the end of the Cold War - an 'interregnum moment' akin to 1919 or $1945 .{ }^{17}$ Inspired by a reductive and teleological informed reading of the significance of 1989, the burgeoning optimism of the post-Cold War period was the defining force in the birth of the concept of peacebuilding. ${ }^{18}$ A new parlance soon emerged to offer hope of a practicable model for this new-found enthusiasm and optimism. Along with concepts of preventive diplomacy, peacemaking, peacekeeping and peace enforcement was the idea of 'postconflict peacebuilding'. This was defined, in consciously pragmatic terms as, 'action to identify and support structures which will tend to strengthen and solidify peace in order to avoid a relapse into conflict'. ${ }^{19}$ AfP suggested a wide range of 'post-conflict peacebuilding' tasks including inter alia 'monitoring elections, advancing efforts to protect human rights, reforming or strengthening governmental institutions, and promoting formal and informal processes of political participation'. ${ }^{20}$ Despite the clear pragmatic compromises entailed in such a rendition of peacebuilding - a statement of intent so broad as to provide a task for almost every agency of the UN system - the ethics of liberal-democracy were explicit in peacebuilding from the beginning. As noted by Boutros-Ghali,

There is an obvious connection between democratic practices - such as the rule of law and transparency in decision-making - and the achievement of true peace and security in any new and stable political order. ${ }^{21}$

Thus, despite its veneer of pragmatism, from its outset, 'post-conflict peacebuilding' was discursively linked to liberal democracy.

I use neoliberalism, in the sense used by $\mathrm{Gill}^{22}$, to characterise the ideological and ethical orientation of peacebuilding, a post-1989 discourse of international intervention. Neoliberalism arose as a disciplinary critique of Keynesianism and state socialism. It was born in the field of economics in the work of Milton Friedman and others of the Chicago School of the 1960s. While it was deployed in the 1980s to adjust the management of the global economy and certain Western national economies, a new generation of economists began to advocate that such practices can be fomented in other parts of the world via international interventions and institution-building. ${ }^{23}$ It thus developed from its disciplinary origins to a form of praxis, adjusted and adapted in context, but always in terms supportive of international political and economic order. Such approaches reflect a rationalist understanding of human affairs, one which embodies a problem-solving ethos and assumes a universal ethical framework. This outlook is conveyed paradigmatically by Francis Fukuyama's End of History thesis. ${ }^{24}$ Neo-liberalism's strategies or 'technologies of governing'25, such as 'structural

${ }^{17}$ Ibid., ch.1.

${ }^{18}$ Boutros Boutros-Ghali. An Agenda for Peace (New York: UN, 1992), p. i

${ }^{19}$ Ibid., 11.

${ }^{20}$ Ibid., 32.

${ }^{21}$ Ibid., 34.

${ }^{22}$ Stephen Gill, 'Globalization, market civilization and disciplinary neo-liberalism', Millennium 24, no.3 (1995): 399-423.

${ }^{23}$ Aihwa Ong, Neoliberalism as exception: mutations in citizenship and sovereignty, (Durham N.C.: Duke University Press, 2006).

${ }^{24}$ Francis Fukuyama, The end of history and the last man, (New York: Free Press, 1992).

${ }^{25}$ Ong, Neoliberalism as Exception. 
adjustment', 'good governance' and 'civil society', are born out of these ethics. Bertram defines UN peacebuilding in messianic terms.

Designed to address the root causes of conflict, it entails building the political conditions for a sustainable democratic peace, generally in countries long divided by social strife, rather than keeping or enforcing peace between hostile states and armed parties. $^{26}$

Sisk, furthermore, asserts the ethical foundations of this approach in unequivocal terms. 'In sum', he notes, 'there is simply no more just or legitimate way to peacefully manage differences among contending social groups than democracy, however difficult it may seem to move from violent to electoral competition' ${ }^{27}$

\section{A Tripartite Discursive Environment}

The explicit pragmatism of such policy-prescriptive statements obscures some very real differences and stymies meaningful debate between interveners. The race to prescribe - to solve problems and find solutions - has plagued peace research from its beginnings as a field. In Robert Cox's terms ${ }^{28}$, it is a form of problem-solving, understood in contrast to critical theory. ${ }^{29}$ This contradiction was already apparent to Schmid in the 1960s who remarked insightfully that 'the universalist ethos of peace research becomes operationalised into identification with the interests of the existing international system'. Thus, it 'becomes a factor supporting the status quo of the international power structure, providing the decision-makers of the system with knowledge for control, manipulation and integration of the system,.$^{30}$ Peacebuilding is no less politicised and, it is argued here, equally susceptible to the power dynamics that Schmid identified in peace research forty years ago. Buzan's critique that peace 'has failed to generate a comprehensive alternative approach to the study of international relations' remains valid in the peacebuilding era. ${ }^{31}$

As Cox and Schmid would recognise, peacebuilding is more than a form of praxis; crucially it is a discourse. In such terms we can begin to understand peacebuilding in its fullness - how and why it is 'expressive', or 'a way to stand for and promote certain ideals'. ${ }^{32}$ Therefore, at first sight, peacebuilding seems to be the very opposite of 'supporting the status quo'. It is a normative approach to intervention which ostensibly demands fundamental institutional changes in post-conflict spaces. It is variously both idealist and pragmatic, performative yet instrumental, interpretatively made and experimentally remade. Experiments 'on the ground' are conceived in a particularly normalising fashion, where it is 'the other' of a conflict zone, rather than

\footnotetext{
${ }^{26}$ Eva Bertram, 'Reinventing Governments: the promises and perils of United Nations peace building.' Journal of Conflict Resolution 39, no.3 (1995), 388

${ }^{27}$ Timothy Sisk, 'Democratisation and Peacebuilding: Perils and Promises,' in Turbulent Peace: The Challenges of Managing International Conflict, eds. Chester Crocker, Fen Osler Hampson and Pamela Aall, (Washington: USIP 2001), 786.

${ }^{28}$ Robert Cox, 'Social Forces, States and World Orders: Beyond International Relations Theory,' in Approaches to World Order, ed. Timothy J. Sinclair (Cambridge: CUP, 1996), 88.

${ }^{29}$ See also A.B. Fetherstone, 'Peacekeeping, Conflict Resolution and Peacebuilding: A Reconsideration of Theoretical Frameworks,' International Peacekeeping 17, no.2 (2000): 190-217.

${ }^{30}$ Herman Schmid, 'Peace Research and Politics', Journal of Peace Research 5, no. 3 (1968), 229

${ }^{31}$ Barry Buzan, 'Peace, Power and Security: Contending Concepts in the Study of International Relations', Journal of Peace Research 21, no.2 (1984), 125.

${ }^{32}$ Lund, 'What kind of peace?', 22
} 
international political and economic structures themselves, which must undergo change to correspond to mythologised international standards. ${ }^{33}$ The reliance upon problemsolving which this entails has suggested, to many, that the ideals of peacebuilding and peacekeeping provide a veneer which barely obscures the policing goals of international actors. ${ }^{34}$

However, many critics of peacebuilding make two analytical missteps which this paper seeks to correct. Firstly, they assume peacebuilding discourse is a cynical construct which barely conceals the true aims of international actors. ${ }^{35}$ In reality, few peacebuilders are cynics and few would see themselves as representatives of the community policing arm of an imperial power. Often markedly internationalist and evangelical, peacebuilders depart significantly from the territorial and timeless national (security) discourses more often studied and deployed by scholars of International Relations. The inclusive worldview of peacebuilding requires the simultaneous construction of both 'friend' and 'enemy' in the other - that is that friend and enemy exist in the same time and space. In the discourse of peacebuilding 'friend' and 'enemy' may even be found in the same individual who is faced with a truncated choice of playing the role of 'spoiler'"36 or a participant in the process. As such the subject is divided, with his/her ethical and political potential taken out of his/her hands and made a product of his/her relationship with the international community. Peacebuilding's world is one of bifurcated time, space and ethics: them and us, then and now, bad and good. It is a world divided between the 'enemy-other' (of the past, fundamentalist ethics and ethnic identity) and an 'ideal-other' (of the future, rationalist ethics and civic identity). The ideal-other is similarly reproduced via the 'us'/'them' boundary where 'they' should become what 'we' imagine ourselves to be. This act of inscription provides meaning, credibility and even legitimacy to interventions. It constructs both 'us' and 'them' in terms of ethical, temporal and spatial markers. ${ }^{37}$

Secondly, and most importantly, many consider peacebuilding to be a single discourse of a singular liberal peace. ${ }^{38}$ However, peacebuilding is not homogenous. Rather than analyse a single international peacebuilding we must explore multiple discourses of the liberal peace. In short we must shift our analytical gaze from peacebuilding to peacebuildings. I distinguish three 'basic discourses' which constitute 'the main structural positions' ${ }^{39}$ within the debate in the International Community:

(i) peacebuilding-via-democratic reform (the original configuration which I refer to above as 'democratic peacebuilding'),

(ii) peacebuilding-via-civil society ('civil society'),

\footnotetext{
${ }^{33}$ It is also true that every major UN report on peace operations over the last fifteen years has recommended some kind of institutional change for the UN. These technical solutions indicate the self-referential nature of peacebuilding whilst leaving unaddressed the broader structures of international order.

${ }^{34}$ David Chandler, Bosnia: faking democracy after Dayton (London: Pluto Press, 1999); François Debrix, Re-Envisioning Peacekeeping: The United Nations and the Mobilisation of Ideology, (Minneapolis: University of Minnesota Press, 1999); Michael Pugh, 'Peacekeeping and Critical Theory.' International Peacekeeping 11, no.1, (2004): 39-58.

${ }^{35}$ Chandler, Bosnia.

${ }^{36}$ Stephen J. Stedman, ‘Spoiler Problems in Peace Processes', International Security, 22:2 (1997): 5-53.

${ }^{37}$ Lene Hansen, Security as Practice: Discourse Analysis and the Bosnian War, (London: Routledge 2006).

${ }^{38}$ Roland Paris, At War's End: Building Peace After Civil Conflict, (Cambridge: Cambridge University Press, 2004).

${ }^{39}$ Hansen, Security as Practice.
} 
(iii) peacebuilding-via-statebuilding ('statebuilding').

This tripartite rendition of peacebuilding is broadly analogous to Banks' concepts of peace; conflict management, justice and order. ${ }^{40}$ The value of Banks' framework is that it captures a fundamental conflict between the key 'meta-ideas'41 of political thought: liberty, justice and order. This tripartite division is similar to the three gradations of the liberal peace - orthodox, emancipatory and conservative - identified in Richmond's germinal study. ${ }^{42}$ This paper seeks to take up his challenge of developing 'a research agenda on the different components of the liberal peace' ${ }^{43}$ An analogical tabulation of concepts of peace and discourses of peacebuilding is shown below (fig. 1).

Fig. 1: Concepts of peace and discourses of peacebuilding

\begin{tabular}{|l|l|l|}
\hline $\begin{array}{l}\text { Concepts of peace } \\
\text { (Banks 1987) }\end{array}$ & $\begin{array}{l}\text { Gradations of the } \\
\text { liberal peace } \\
\text { (Richmond 2005) }\end{array}$ & $\begin{array}{l}\text { Discourses of } \\
\text { peacebuilding }\end{array}$ \\
\hline Conflict management & Orthodox & Democratic peacebuilding \\
\hline Justice & Emancipatory & Civil Society \\
\hline Order & Conservative & Statebuilding \\
\hline
\end{tabular}

This schematic is at best a rough sketch of the overlaps between peace concepts and peacebuilding discourses. However, it is not too much of a stretch to locate proponents of civil society such as Kaldor ${ }^{44}$ in a justice tradition, and proponents of statebuilding such as Berger \& Scowcroft ${ }^{45}$ as advocates for international and domestic order. Equally, it is not overly contrived to contrast the work of Lederach ${ }^{46}$ with that of Fukuyama $^{47}$ as they are broadly addressing the same questions of conflict resolution but from very different perspectives. The possibilities and limits of the analogousness of concepts of peace and discourses of peacebuilding are most pronounced in Banks work. In so far as he himself favoured peace-as-conflict-management from within the liberal or rationalist tradition - 'a dynamic state of affairs in which the essential properties arise from how we do things not what we do" ${ }^{48}$ - he represents the optimism of the dawn of peacebuilding in the late-1980s. Banks argued that a justice-based approach is concerned with poverty-alleviation and self-determination, concerns which are paramount in civil society peacebuilding today. By contrast he remarks that peace-asorder proponents seek 'life made predictable and relatively safe' ${ }^{49}$ In international

\footnotetext{
${ }^{40}$ Banks, 'Four Concepts of Peace'

${ }^{41}$ The term 'meta-ideas' is used with respect to the concept of peace in MacGinty, No War, No peace, 19.

${ }_{42}^{42}$ Richmond, The Transformation of Peace, 214.

${ }^{43}$ Ibid., 230.

${ }^{44}$ Mary Kaldor, New and Old Wars: Organized Violence in a Global Era, (Cambridge: Polity Press 2001); Mary Kaldor, 'Reconceptualising Organised Violence,' in Re-imagining Political Community: studies in cosmopolitan democracy, eds. Daniele Archibugi, David Held and Martin Köhler, (Cambridge: Polity Press, 1998): 91-110

${ }^{45}$ Samuel R. Berger \& Brent Scowcroft, 'In the Wake of War: Getting Serious about NationBuilding', National Interest 81 (Fall 2005): 49-53.

${ }^{46}$ John Paul Lederach, The Moral Imagination: The Art and Soul of Building Peace, (New York: OUP, 2005).

${ }^{47}$ Francis Fukuyama, State-building: governance and world order in the 21st century, (Ithaca, New York: Cornell University Press 2004).

${ }^{48}$ Banks, 'Four Concepts of Peace', 269

${ }^{49}$ Ibid., 261.
} 
relations this means they describe and prescribe 'an ordered hierarchy which maintains a rudimentary form of world government whereby the affairs of the smaller and weaker states are directed by the larger and more powerful ones'. ${ }^{50}$ Such assessments seem at once to depart from the unilateralism of neo-conservative American statebuilders yet eerily foreshadow critical analyses of imperial statebuilding in Kosovo, Afghanistan and $\mathrm{Iraq}^{51}$ and the development of a new norm of contingent or 'positive' sovereignty which makes such practices legitimate. ${ }^{52}$

The response from within peace studies to this muddying of their foundational concept and ethic has often been incoherent. In the recent second edition of a leading survey, Ramsbotham, Woodhouse, and Miall assert the need to rediscover the foundational concepts of the field.

We have aimed to reclaim terms such as conflict resolution and conflict transformation $[\ldots]$ from those who misuse them, by explaining clearly how they are understood within the conflict resolution tradition. As in the case of appeals to freedom and democracy, we argue that those who invoke these concepts should ensure that their purposes and actions are consonant with them - or else stop using such language. ${ }^{53}$

The authors do not imply that there are such things as 'conflict resolution' or 'peace' out there, objectively existing in the world, the blueprint to which is waiting to be discovered by mankind, but merely claim that there is an appropriate tradition of interpretation that should be adhered to. However, such normative re-statements of a peace tradition are chimerical and risk making the field irrelevant to the empirical questions of peacebuilding. As Buzan notes essentially contested concepts such as peace cannot simply be fixed or 'defined in strict terms'. ${ }^{54}$ Peace and peacebuilding, according to such a view, 'represent durable and coherent domains of concern' which 'have their own set of norms and assumptions' as well as 'containing contradictions, which is what prevents their being expressed in universally accepted definitions'. ${ }^{55}$ As such peace and peacebuilding are not terms with a proper descriptive utility and normative value which can be 'reclaimed' but they are political discourses which represent and serve to justify certain political interests and ideas.

My approach is through discourse analysis and is but one of many attempts to probe the problematic of peace. Some conceptualisations of peace or peacebuilding conflate meta-epistemological sources, meta-ideas and concepts. MacGinty, for example, identifies three meta-ideas of the religious-spiritual, humanity and sustainability. ${ }^{56}$ In reality, secular humanism and religious faith can provide inspiration and support to all three concepts of peace outlined above. Richmond, by contrast, identifies nine concepts or 'main methods' of peace, the features of many of which are reframed in my tripartite framework. ${ }^{57}$ The relatively parsimonious approach adopted

\footnotetext{
50 Ibid.

${ }^{51}$ Simon Chesterman, 'Bush, the United Nations and Nation-building,' Survival 46, no.1 (2004): 101-116; David Chandler, Empire in Denial: The Politics of State-building, (London: Pluto, 2006).

52 Dominc Zaum, The Sovereignty Paradox: The Norms and Politics of International Statebuilding (Oxford: OUP, 2007).

${ }^{53}$ Oliver Ramsbotham, Tom Woodhouse and Hugh Miall, Contemporary conflict resolution: the prevention, management and transformation of deadly conflicts (Cambridge: Polity, 2005, 2nd ed), xiii.

${ }^{54}$ Buzan, 'Peace, Power and Security', 125

${ }^{55}$ Ibid.

${ }^{56}$ MacGinty, No War, No Peace, 19-24.

${ }^{57}$ Richmond, The Transformation of Peace.
} 
here may raise as many questions (and potentially obscure as many differences) as it provides answers. It risks oversight and conflation whilst seeking to avoid confusion and obfuscation. This paper ignores critical discourses such as those identified and advocated by inter alia Bendana and Fetherstone. ${ }^{58}$ More importantly it excludes grounded local and regional discourses of peace which generate context-specific responses to international intervention in post-conflict environments. In my own work on Tajikistan, I have identified basic popular and elite discourses which not only determine local and regional reactions but also serve as foundations for the peace that has emerged there since the late-1990s. ${ }^{59}$ Yet my research also indicates that international peacebuilding discourses tend to be reproduced internationally even when their impact on their target populations is negligible or even counter-productive. ${ }^{60}$ Thus, the concern in this paper is to highlight the endogenous dynamics of discursive reproduction and evolution in the international context. Nevertheless it serves as merely an initial or basic illustration of the discursive environment of the so-called liberal peace.

\section{Dividing: civil society versus statebuilding}

The ethical, spatial and temporal orientations of democratic peacebuilding are to a certain extent shared by civil society and statebuilding discourses. Indeed, the intertextual links between the three are so voluminous that it is difficult to separate them for the purpose of analysis. Most analysts, following Paris ${ }^{61}$, simply discuss a single discourse of the 'liberal peace'. However, such critiques often obscure important differences that have emerged in the fifteen years since Boutros Boutros-Ghali launched Agenda for Peace. On the one hand, advocates of 'civil society' have argued for NGOs as agents of peacebuilding from the 'bottom-up'; engaging in complex emergencies through conflict prevention, multi-track diplomacy and the creation of 'local capacities for peace'. ${ }^{2}$ On the other hand, the recent enthusiasm for 'statebuilding' from the 'top-down' seeks stabilisation, security first and 'institutionalisation-before-liberalisation'. ${ }^{63}$ The contentions between these two approaches (or discourses) represent the terms of the peacebuilding debate over the last fifteen years. More importantly, conservative statebuilding and humanitarian civil society offer contrasting emphases in terms of space, and contending ethical stances of order and justice. While in the 1990s, the international community rushed to civil society as an engine of social justice, in recent years - particularly since September $11^{\text {th }}, 2001$, and the launch of the 'war on terror' - statebuilding has gained new currency among many in the international community, particularly the US Government.

\section{Civil Society: peace-as-justice}

The idea of 'civil society' as an agent of post-conflict change emerges from a justice ethic that has been at the heart of peace studies since its genesis during the Cold War. Galtung's work on positive peace, as well as other foundational peace studies work

\footnotetext{
${ }^{58}$ Bendana, What Kind of Peace; Fetherstone, 'Peacekeeping'.

${ }^{59}$ John Heathershaw, 'Peacebuilding as Practice: Discourses from Post-Conflict Tajikistan', International Peacekeeping 14, no.2 (2007): 219-236

${ }^{60}$ John Heathershaw, 'Seeing like the International Community: How Peacebuilding Failed (and Survived) in Tajikistan', Journal of Intervention and Statebuilding. 2, no. 3 (2008),

forthcoming.

${ }^{61}$ Paris, At War's End.

${ }^{62}$ Mary Anderson, Do No Harm: How Aid Can Support Peace - Or War (Boulder: Lynne Rienner, 1999).

${ }^{63}$ Paris, At War's End.
} 
such as Azar's concept of 'protracted social conflicts' and Burton's 'deep-rooted conflicts' and 'basic human needs' have contributed to the peace as justice tradition. ${ }^{64}$ More recently many such scholars have come to focus on 'relationships' or 'people-topeople' peacebuilding. ${ }^{65}$ Two commensurable peace-as-justice orientations remain hugely influential in the development of conflict resolution theory and practice; Christian humanism and secular humanitarianism and developmentalism.

Religious groups, including those of a Christian or Gandhian hue, are often amongst the primary actors in peacebuilding projects. Foremost among the exponents of this Christian humanist perspective is John Paul Lederach, who defines peacebuilding as the transformation of 'conflict toward more sustainable, peaceful relationships' ${ }^{66}$ Such relationships, according to Lederach, are held together by four 'social energies' - Brother Justice, Sister Truth, Brother Mercy, and Sister Peace. This represents an understanding of peace which he takes directly from Psalm 85. Rather than advocate grand strategies or institutions, Lederach recommends the creation of social spaces of reconciliation. ${ }^{67}$ Such spaces are brought about in part by the deliberate action of peacemakers and in part by a divinely inspired meeting of minds which is explored in most detail in his latest work, The Moral Imagination. 'Transcending violence,' he contends, 'is forged by the capacity to generate, mobilise, and build the moral imagination'. ${ }^{68}$

The idea of 'civil society' brings this kind of community peace work from the religious fringes into the secular mainstream. This was exhibited in an emphasis on the role of the military in humanitarian operations from the mid-1990s (see Slim 1996), and the massive expansion of the role of international NGOs and their local subcontracting partners in post-conflict settings. Here relational and contextual approaches are usurped by generalisable models focused on SMART targets and adaptable to locations across the globe. ${ }^{69}$ Civil society proved a popular alternative with donors when state-centric democratic peacebuilding experienced public and undeniable failure. The high-profile tragedies of the early-1990s in Africa and the Balkans, led to substantial criticism of the UN and third-party intervention more generally ${ }^{70}$ Within the international community such criticism led, for many donors, to an increased interest in civil society approaches through NGOs. Thus, the negative experiences and 'lessons learnt' of Rwanda and Somalia demnded attempts to engage more at the 'grassroots', with 'civil society', and avoid 'state-centric' approaches. Suddenly civil society-based approaches such as 'multi-track diplomacy' and 'local capacities for peace' became en vogue in international discourse. ${ }^{71}$ Such authors even demanded the

${ }^{64}$ Johan Galtung, 'Three Approaches to Peace: Peacekeeping, Peace-making and Peacebuilding,' in Peace, War and Defence - Essays in Peace Research 2, (Copenhagen: Christian Ejlers, 1975): 282-304; see, Edward E. Azar, and John W. Burton eds. International conflict resolution: theory and practice (Boulder, Colo. : Wheatsheaf : L. Rienner Publishers, 1986); John Burton, Conflict: resolution and prevention (Basingstoke: Macmillan, 1990).

${ }^{65}$ John Paul Lederach, Building Peace: Sustainable Reconciliation in Divided Societies, (Washington, DC: United States Institute of Peace Press, 1997); Michelle I. Gawerc, 'Peacebuilding: theoretical and concrete perspectives,' Peace and Change 31, no.4 (2006): 435-478.

${ }^{66}$ Lederach, Building Peace, 20.

${ }^{67}$ Ibid., 29.

${ }^{68}$ Lederach, The Moral Imagination, 5.

${ }^{69}$ SMART targets are specific, measurable, attainable, realistic and time-limited.

${ }^{70}$ Ben Barber, 'Feeding Refugees, or War? The dilemma of humanitarian aid,' Foreign Affairs 76, no.4, (1997): 8-14; Edward N Luttwak, 'Give War a Chance.' Foreign Affairs 78, no.4, (1999): 36-48.

${ }^{11}$ Chester Crocker, Fen Osler Hampson, and Pamela Aall, eds, Herding cats: multiparty mediation in a complex world, (Washington D.C.: United States Institute of Peace Press, 1999); Mary Anderson, Do No Harm: How Aid Can Support Peace - Or War (Boulder: Lynne 
re-conceptualisation of war to mark out changes in its practice since the Cold War era with Kaldor drawing a fashionable distinction between 'new' and 'old' wars. ${ }^{72}$ New wars require new approaches, it was argued, at the level of civil society.

However, the development of new techniques for civil society peacebuilding obscures a highly political debate on the nature of civil society between radicals and moderates. In its most radical form, civil society peacebuilding demands the taming of power politics for humanitarian ends as in Kaldor's hope for a 'robust peacekeeping'. The key question, she argues, is 'whether the capacity for regulating violence can be reinstituted in some way on a transnational basis and whether barbarism can be checked by an alert and active cosmopolitan citizenry'. ${ }^{73}$ Yet most civil society actors obfuscate or deny their political potential by continuing to emphasise their apartness from politics. Criticism of the 'neutrality' principle led civil society actors to recast it as a contingent 'impartiality', understood paradigmatically in terms of 'do no harm' ${ }^{74}$ However, this restatement of humanitarian ethics once again refuses to recognise the extent of the broader political and economic contexts which aid agencies inhabit. ${ }^{75}$ Gawerc, for example, after considering radical and political realist critiques of 'peopleto-people' peacebuilding, notes, 'in many ways, it comes down to whether conflict groups trust each other with regard to the purpose of integrative/cross-cutting ties' ${ }^{76}$ This simplistic reduction of civil society to a universal human institution is a moderating, depoliticising move which obscures the conflicts of interests and idea found between peacebuilding discourses.

\section{Statebuilding: peace-as-order}

Despite the growing strength of the idea of civil society in the peacebuilding discourse of the mid-1990s, the political dynamics of the International Community were engendering a U-turn in policy priorities. This statebuilding approach can be considered a new iteration of peace-as-order in that it relegates the pacifying powers of civil society via a conservative or realist discourse of politics. In apparent retreat to a minimalist reading of peacebuilding, Boutros-Ghali reaffirmed, in the supplement to Agenda for Peace of 1995, that, 'respect for [the State's] fundamental sovereignty and integrity are crucial to any common international progress' ${ }^{77}$ This emphasis on sovereignty and the norm of non-intervention ironically foreshadowed the later development of statebuilding and increasing move away from non-intervention. Contemporary advocates of state-building insist on the primacy of the sovereign state in post-conflict spaces whilst arguing that such states must be built under conditions of international military intervention. It is this normative contradiction which is the primary feature of statebuilding discourse. Statebuilding is wrought by contradiction in

\footnotetext{
Rienner, 1999).

${ }^{72}$ Mary Kaldor, New and Old Wars: Organized Violence in a Global Era, (Cambridge: Polity Press 2001).

${ }^{73}$ Mary Kaldor, 'Reconceptualising Organised Violence,' in Re-imagining Political Community: studies in cosmopolitan democracy, eds. Daniele Archibugi, David Held and Martin Köhler, (Cambridge: Polity Press, 1998), 107-109.

${ }^{74}$ Anderson, Do No Harm.

${ }^{75}$ Mark Duffield, Global Governance and the New Wars: the Merging of Development and Security, (London: Zed Books, 2002).

${ }^{76}$ Gawerc, 'Peace-building', 461.

${ }^{77}$ Boutros Boutros-Ghali, Supplement to an Agenda for Peace: Position Paper of the Secretary General on the Occasion of the Fiftieth Anniversary of the United Nations, 3 January 1995, $\mathrm{A} / 50 / 60-\mathrm{S} / 1995 / 1,103,105$.
} 
offering an even stronger challenge to the principle of non-intervention in domestic affairs than that implied by radical 'civil society' discourse.

Statebuilding texts bear resemblance to explanations of incremental political development emanating from a further related body of literature - that of modernisation. Modernisation in turn shares significant ground with pact-based and institutionalist understandings of democratisation and involves some of the same theoreticians. Samuel Huntington in an earlier influential work, Political Order in Changing Societies, utilises an explicitly conservative understanding of political development where modernisation is the institutionalisation of power relations. His 1968 study begins,

The most important political distinction among countries concerns not their form of government but their degree of government. The differences between democracy and dictatorship are less than those countries whose politics embodies consensus, community, legitimacy, organisation, effectiveness, and stability, and those countries where politics is deficient in these qualities. ${ }^{78}$

Such order-based explanations of change relegate social justice or wider political participation to matters of secondary importance. Modernisation has gone out of fashion as an approach to development. However, many similar ideas, and some of the same authors are popping up today to advocate an approach of 'nation-building' or 'state-building'. These terms are often used interchangeably in policy discourse.

The target of statebuilding is the 'failed state'. A failed state, to state-builders, who are often political realists, is an environment much like international anarchy. Cohen et al's seminal article argued that the degree of anarchy, or 'the lower the initial level of state power, the stronger the relationship between rate of state expansion and collective violence' ${ }^{79}$ The discursive development of 'statebuilding' and its subject of the 'failed state' intensified in the early-1990s following Jackson's influential study of quasi-states. ${ }^{80}$ Helman \& Ratner and Zartman used the notions respectively of 'failed' and 'collapsed' states to explain the crises of post-colonialism, particularly in Africa. ${ }^{81}$ In 1994, the CIA funded a multi-year, multi-disciplinary research programme named The State Failure Task Force. Yet following the failures of the early-1990s, the retreat of Supplement to Agenda for Peace and the Clinton administration's return to a more multilateral approach to foreign policy 'state failure' lost profile as a discursive signifier.

In the twenty-first century statebuilding has enjoyed a second wind. As Call observes, it was the 9/11 attacks which, 'drew attention to state failure, bring 'failed states' into the top tier of US security interests'. ${ }^{82}$ The subsequent 2002 US National Security Strategy identified 'failing' states as a source of insecurity and terrorism. ${ }^{83}$ Thus the academic idea of the 'failed state' has been incorporated in the grand

\footnotetext{
${ }^{78}$ Samuel P. Huntington, Political order in changing societies, (New Haven, Yale University Press, 1968), 1.

${ }^{79}$ Youssef Cohen, Brian R. Brown and A.F.K. Organski, 'The Paradoxical Nature of StateMaking: The Violent Creation of Order,' American Political Science Review 75, no.4 (1981), 905.

${ }^{80}$ Robert H. Jackson, Quasi-States: Sovereignty, International Relations and the Third World, (Cambridge: CUP, 1990).

${ }^{81}$ Gerald Helman and Steven Ratner, 'Saving Failed States,' Foreign Policy 89 (Winter 19921993): 3-20; William I. Zartman, Collapsed states : the disintegration and restoration of legitimate authority, (Boulder, Colo. : London : L. Rienner, 1995).

${ }^{82}$ Charles Call, 'The Fallacy of the 'Failed State',' a paper presented at the International Studies Association annual meeting, San Diego, 25 March 2006, 20-21.
} 
narratives of policy-makers, and developed as the justification for interventions and post-conflict operations in Afghanistan and Iraq under the mantra of the 'war on terror'. ${ }^{84}$ In this context, statebuilding is often labeled as 'nation-building' ${ }^{85}$ Similarly, a recent book by Francis Fukuyama defines the process of statebuilding as, "the creation of new government institutions and the strengthening of existing ones' ${ }^{86}$ Military force is seen as intrinsic to this process, as in Dobbins' definition of statebuilding: 'to use military power in the aftermath of a conflict to underpin an enduring transition to democracy, ${ }^{87}$ US government and military representatives have come to use the title 'stabilisation and reconstruction' to describe this process. ${ }^{88}$

By 2008, statebuilding and its enemy and ideal others of the 'failed' and 'sovereign' state, had risen to be the dominant theme of peacebuilding discussions and had developed a substantial academic, policy-making and even popular literature. ${ }^{89}$ The number of research projects aimed at identifying variables and 'measuring' state sovereignty in quantitative and qualitative terms proliferated. Those who made their names in the critique of democratic peacebuilding are now oft-cited advocates for statebuilding. ${ }^{90}$ One project measured state sovereignty with a quantitative index in order, to 'allow an overall assessment to be made of whether the multiplicity of interventions by a wide array of international actors is closing or widening the sovereignty gap'. ${ }^{91}$ This notion of 'sovereignty gap' exhibits both a normative preoccupation and an objectivist understanding of state sovereignty.

The principal and rather obvious problem with this idea of an objective process of statebuilding is that it fails to grasp the vital subjective and symbolic dimensions of state sovereignty and political authority more broadly. Policy-makers pay lip-service to these dimensions whilst never exploring their logical consequences. For example, former US Ambassador to Afghanistan and later Ambassador to Iraq, Zalmay Khalilzad, defines US efforts in Afghanistan under this mantra as the effort to 'establish a legitimate political process and rebuild state institutions'. ${ }^{92}$ Yet legitimacy, as is almost universally accepted in the academy, has a subjective or inter-subjective quality. ${ }^{93}$ It is deemed or interpreted. In other words it is produced in forms of consent,

\footnotetext{
${ }^{83}$ United States of America, The National Security Strategy of the United States of America. 2002. http://www.whitehouse.gov/nsc/nss.html, September 2002, accessed: 11 Nov. 2005, 1

${ }^{84}$ For a defence of such operations see, Zalmay Khalilzad, 'How to Nation-Build: ten lessons from Afghanistan,' The National Interest 80 (Summer 2005): pp.19-28; for a critique of their application in Iraq see Charles Tripp, 'The United States and state-building in Iraq.' Review of International Studies 30, no.4 (2004): 545 - 58.

${ }^{85}$ Chesterman, 'Bush, the United Nations and Nation-building', 114.

${ }^{86}$ Fukuyama, Statebuilding.

${ }^{87}$ James F. Dobbins, 'America's Enduring Role in Nation Building: From Germany to Iraq,' Survival 45, no.4, (2003-2004), 87.

${ }^{88}$ Berger and Scowcroft, 'In Wake of War'.

${ }^{89}$ For a discussion of the rise of statebuilding see, John Heathershaw and Daniel Lambach, 'Introduction: Post-Conflict Spaces in International Relations', Journal of Intervention and Statebuilding 2, no. 3 (2008), forthcoming.

${ }_{90}$ Paris, At War's End.

${ }^{91}$ Ashraf Ghani, Clare Lockhart and Michael Carnahan, Closing the Sovereignty Gap: An Approach to State-Building, Overseas Development Institute, Working Paper 253, London, September 2005, 5.

${ }^{92}$ Ibid., 1, my emphasis.

${ }^{93}$ For a rendition of legitimacy as a subjective concept related to identity see, Rodney Barker, Legitimating Identities: the self-presentations of rulers and subjects (Cambridge: CUP, 2001); for an inter-subjective conceptualisation see, David Beetham, The Legitimation of Power (London: MacMillan 1991).
} 
institutions and rules, and maintained by beliefs. ${ }^{94}$ Thus, it is unclear how it can be based exclusively on increased material resources and the ostensible reform of formal institutions of governance, particularly those supplied or demanded by external powers. This fundamental contradiction of statebuilding is inherent with the ongoing failure of US-led missions in Iraq and Afghanistan to actually build a state which is not entirely reliant on the support of occupying forces.

${ }^{94}$ Beetham, The Legitimation of Power. 


\title{
Merging: 'Pragmatic' Peacebuilding
}

It is readily apparent that peacebuilding as an analytical concept is 'elastic' or even amorphous. ${ }^{95}$ The application of liberalisation of both the economy and political system to post-conflict spaces takes place without substantive empirical evidence of success. In this vein, ten years after AfP, Lund argued for an evaluation and consolidation of existing approaches to peacebuilding.

\begin{abstract}
A line needs to be drawn between peacebuilding and maximising the various levels of social, economic and political development possible in a given society. Otherwise, if the term peacebuilding becomes a synonym for all the positive things we would want to include in development in order to reduce any and all of societies' ills, it becomes useless for guiding knowledge gathering and practical purposes. ${ }^{96}$
\end{abstract}

There are few in the study and practice of peacebuilding that would disagree with this noble aim. Considering themselves to be pragmatists, they offer moderate critiques of international practice but reproduce the basic discursive environment that includes and blends the three neoliberal alternatives of democratic peacebuilding, civil society and statebuilding.

This merging of peacebuilding discourses is difficult to analyse. Poststructuralist discourse analysts chart 'inter-textuality' - the referencing (or plagiarising) of texts in other texts. This is a useful strategy with regard to the academic literature on peace operations yet is of limited utility with respect to policy and programmatic literature. Many recent policy texts have been written or influenced by academics and have been heavily influenced by other policy and academic studies. ${ }^{97}$ Indeed, there is extraordinary and apparently growing cross-fertilisation between the academic and policy worlds as academics are employed as consultants and research is increasingly purchased by international donors. ${ }^{98}$ However, a major UN report, for example, is unlikely to include more than a bare minimum of references and acknowledgements. Nevertheless one can observe more broadly (and less precisely) how these reports incorporate the hegemonic ideas of the academic and policy worlds with regard to peacebuilding. This final part reveals some of this inter-textuality and hegemonic incorporation in peacebuilding.

\section{Incorporation to one standard model: policy developments}

Recent international reports on intervention and peace operations have sought to consolidate peacebuilding through the incorporation of moderate criticism and a strategic policy realignment which reflects the rise of statebuilding discourse. The Brahimi Report of 2000, for example, attempted something of a discursive re-joining of military and humanitarian intervention through the notion of interdependent peacekeeping and peacebuilding. Accordingly, 'force alone cannot create peace; it can

\footnotetext{
${ }^{95}$ Charles-Philip David, 'Does Peacebuilding Build Peace? Liberal (Mis)steps in the peace process,' Security Dialogue 30, no.1 (1999): 25-41.

${ }_{96}^{96}$ Lund, What kind of peace?, 28.

${ }^{97}$ For example, the UN report, A More Secure World, was lead-authored by Stephen Stedman with the assistance of other policy-practitioners. The 2005 Human Security Report was authored by Andrew Mack and colleagues at the University of British Columbia. ${ }^{98} \mathrm{An}$ interesting discussion of the reasons for this out-sourcing of expertise by the International Community is found in Duffield, Global Governance and the New Wars, 257265 .
} 
only create the space in which peace must be built' ${ }^{99}$ Similarly, the report of the International Commission on Intervention and State Sovereignty (ICISS), The Responsibility to Protect (R2P) blends a humanitarian civil society perspective with that of statebuilding and explicitly challenges the ambiguity with regard to state sovereignty found in AfP. ${ }^{100}$ R2P seeks to push the frequency, duration and extent of intervention beyond that implied by democratic peacebuilding by including the responsibilities to prevent, react and rebuild. ${ }^{101}$ However, it places emphasis first on the protection of the individual, rather than the constitution of a system of sovereign states. Furthermore, the authors that the International Community is represented most legitimately by the United Nations rather than a state or states which claim to act on the part of the 'international community'. ${ }^{02}$ They demand a just cause based on the prevention of 'large scale loss of life' and 'large scale 'ethnic cleansing',' and adapt the principles of Augustinian just war as the basis for military intervention. ${ }^{103}$

This merging of justice and order is emblematic of the practices of incorporation in peacebuilding's discursive environment. The Report of the UN HighLevel Panel on Threats, Challenges and Change, A more secure world: Our shared responsibility (MSW) ${ }^{104}$ draws on $\mathrm{R} 2 \mathrm{P}$. MSW places the state as the primary subject of peacebuilding but maintains the ideal of the universal space of the International Community, where a universal model of state sovereignty must be adhered to in order to preclude international intervention. While the report addresses collective security in its broadest sense, one of its headline conclusions was the proposal for a Peacebuilding Commission, 'whose task', wrote Kofi Annan in the foreword to the MSW report, 'would be to help states make a successful transition from the immediate post-conflict phase to longer-term reconstruction and development'. ${ }^{105}$

These proposals represent an emerging peacebuilding meta-discourse which attempts to reconcile the various ethical, spatial and temporal ideals represented in the three discourses outlined above. As such MSW seeks to please everyone - both humanitarians who demand that the rights of the individuals must be placed above the sovereignty of the state, and statebuilders who believe that juridical sovereignty should be built from without in the case of 'failed states.' It is thus highly interventionist. The Peacebuilding Commission is envisioned as a part of the UN system in order 'to identify countries which are under stress and risk sliding towards state collapse' ${ }^{106}$ 'Today,' the report notes, 'we are in an era where dozens of states are under stress or recovering from conflict, there is a clear international obligation to assist states in developing their capacity to perform their sovereign functions effectively and

\footnotetext{
${ }^{99}$ United Nations, The Report of the Panel on United Nations Peace Operations ['The Brahimi Report'], 2000, available at: http://www.un.org/peace/reports/peace-operations/, accessed: 14 June 2004.

${ }^{100}$ ICISS was established by the Canadian Prime Minister, Jean Chrietien, in September 2000 in response to Kofi Annan's challenge to the UN General Assembly to unite on the question of 'humanitarian intervention' following the Kosovo military intervention of 1999.

${ }^{101}$ International Committee on Intervention and State Sovereignty, Responsibility to Protect (Ottawa: International Development Research Centre, 2001), xi.

${ }^{102}$ Ibid., 9. The commission in fact avoids using the term of 'humanitarian intervention' in order to respond to the concern of self-styled humanitarian relief agencies that the term humanitarian is being militarised by such military interventions.

${ }^{103}$ Ibid., .xii.

${ }^{104}$ United Nations, A More Secure World: Our shared responsibility, Report of the SecretaryGeneral's High-Level Panel on Threats, Challenges and Change, (UN: New York 2004), 1 emphasis added.

${ }^{105}$ Ibid., ix.

${ }^{106}$ Ibid., 83.
} 
responsibly' ${ }^{107}$ If these powers were institutionalised, the Commission would shift the UN further away from principles of sovereign consent and blur the distinctions between peacebuilding and peace enforcement. MSW amounts to the clearest case for a two-tier system of sovereign states (subjects of intervention and objects of intervention) since nineteenth century advocacy for colonialism.

Policy texts such as R2P and MSW indicate that while the three discourses are analytically separable they are in no sense independent from one another. Civil society peacebuilding and statebuilding, whilst articulated against one another, are both strongly interdependent. They are often explored in the literature on peacebuilding in terms of bottom-up and top-down dynamics based on, respectively, the concepts of 'civil society' and 'good governance'. Prendergast and Plumb, for example, argue that, 'there needs to be, alongside the top-down implementation of the peace agreement, concurrent bottom-up processes aimed at constructing a new social contract and healing societal divisions'. ${ }^{108}$ In the International Community this remains a persuasive argument for the incorporation of contrasting orientations into a synthesised concept of peacebuilding. In such terms those involved in interventions explicitly disregard any theoretical bias or ideological bent to their work, claiming simply that it is both pragmatic and broad in scope.

\section{Incorporation in praxis: the merging of development and security}

Incorporation exists not merely at the level of high-policy but dramatically affects the practices, programmes and relationships on the International Community. Mark Duffield has charted this from the mid-1990s in terms of the merging of development and security. ${ }^{109}$ This process of merging, he argues, has had two phases which correlate with the births of apparently contending civil society and statebuilding discourses. The first phase was the incorporating of the language of security by non-governmental actors into humanitarian discourse and the concomitant adoption of developmentalist language by militaries and defence ministries. Duffield shows how this began with the post-Cold War 'radicalisation' of development and its incorporation to peacebuilding. This launched the concepts of 'Security Sector Reform' (SSR) and 'human security' in the mid-1990s and made security a humanitarian issue. SSR thus became a conceptually credible representation of the merger of security and development. The German Development Corporation, for example, and with reference to the UN Development Programme, equated SSR with 'guaranteeing human security' as well as 'national security' - an approach which has also been adopted by the OSCE. ${ }^{110}$ The merging of security and development remains a powerful discourse. 'Packaged so neatly,' Chanaa notes, 'it was easy to present, attracting not only attention, but also considerable material support' ${ }^{111}$

Since 9/11, however, a second stage has ensued where SSR and development have been re-inscribed once more in terms of statebuilding, with a limited role for civil society actors. This has corresponded with a significant rise in military assistance by the United States, particularly to Afghanistan and Iraq, but also to other equally

\footnotetext{
${ }^{107}$ Ibid., emphasis added.

${ }^{108}$ John Prendergast, and Emily Plumb, 'Building Local Capacity: From Implementation to Peacebuilding', in Ending civil wars: the implementation of peace agreements, eds. Stephen John Stedman, Donald Rothchild, and Elizabeth M. Cousens, (Boulder, Colorado: Lynne Rienner, 2002), 327-349.

${ }^{109}$ Duffield, Global Governance and the New Wars.

${ }^{110}$ Jane Chanaa, Security Sector Reform: Issues, Challenges and Prospects. Adelphi Paper 344 , (Oxford: Oxford University Press for the International Institute for Strategic Studies, 2002), 27.

${ }^{111}$ Ibid., 27.
} 
problematic state partners under the war on terror such as Uzbekistan from 2002-2005. Duffield's work highlights the significance of this merger of security/development for the nature of world order. Writing at the end of the 1990s he notes with far-sightedness that 'the idea of underdevelopment as dangerous and destabilising provides a justification for continued surveillance and engagement [in countries of the global South]'. ${ }^{112}$ The idea of dangerous underdevelopment - embodied in tropes such as 'failed states', 'bad civil society' and 'extremism' - is replete through major policy texts put out by development and defence ministries alike. 'Failed states', for example, serves as a justification for statebuilding interventions in both the US National Security Strategy of 2002 and the UK Departmentfor International Development White Paper of $2006 .{ }^{113}$ Duffield is surely right to see in the merging of development and security 'that liberal peace contains within it the emerging structures of liberal war' (2001: 15). In Duffield's terms, the contemporary discursive environment of peacebuilding indicates 'a susceptibility within global liberal governance to normalise violence and accept high levels of instability as an enduring if unfortunate characteristic of certain regions'. ${ }^{114}$

\section{Incorporating critique: a new dogma?}

Perhaps the strongest indicator of this inter-textual process of synthesis is found in how apparently critical works are incorporated by discourse and become the new dogma. In such a way apparent critiques become the new grand strategy for peacebuilding which reflects discursive developments (towards statebuilding) and looks not all that dissimilar from their predecessors. The influential works of Roland Paris offer a moderate critique which has provided momentum to the new peacebuilding-cumstatebuilding direction of pragmatists.

Paris, in a widely cited article, 'Wilson's Ghost', argued that peacebuilding is guided by the doctrine of liberal internationalism while 'transplanting western models of social, political, and economic organisation into war-shattered states'. ${ }^{115}$ A standard operating procedure for liberalisation - involving competitive elections and a reduced role for the state in the economy - was adopted, often counter-productively, in all fourteen cases reviewed by Paris in a later study. ${ }^{116}$ His work contributes to a weight of qualitative evidence suggesting that actual post-conflict cases can rarely be made to fit the criteria for successful peacebuilding. Yet while Paris's earlier work was critical of peacebuilding, his more recent reform-orientated work has been consistently moderate. He calls for an adjustment of peacebuilding practice in terms of 'institutionalisation before liberalisation' (IBL), thus 'avoiding the pathologies of liberalisation, while placing war-shattered states on a long-term path to democracy and market-oriented economics' ${ }^{117}$ He characterises this as the thought of 'classical liberal theorists' rather than 'Wilsonianism', ${ }^{118}$ but this approach is remarkably similar to Huntington's developmentalism of the $1960 \mathrm{~s}^{119}$ and in this sense it reflects and furthers

${ }^{112}$ Duffield, Global Governance and the New Wars, 7.

${ }^{113}$ USA, National Security Strategy; Department for International Development [DFID], Eliminating World Poverty: making governance work for the poor, white paper of the UK Government, July 2006.

${ }^{114}$ Ibid, 17.

${ }^{115}$ Roland Paris, 'Peacebuilding and the Limits of Liberal Internationalism', International Security 22, no.2, (1997), 56; see also, Roland Paris, 'International peacebuilding and the 'mission civilisatrice." Review of International Studies 28, no.4 (2002): 637-656.

${ }^{116}$ Paris, At War's End.

${ }^{117}$ Paris, At War's End, 235.

${ }^{118}$ Ibid.

${ }^{119}$ Michael Dodson, 'Postconflict Development and Peace Building: Recent Research.' Peace \& Change 31, no.2, (2006), 246. 
an overall discursive trend towards statebuilding. ${ }^{120}$ As Paris himself puts it peacebuilding must involve, 'building liberal and effective states'. ${ }^{121}$ At the same time his work emphasises the need to promote 'good civil society' and 'control hate speech', much like civil society peacebuilding. ${ }^{122}$

However, this search for a new consensus represents less of a shift away from the liberal peace than the author imagines. Moreover, the manner in which Paris develops his argument serves to regenerate the very hegemonic liberal peace which he seeks to critique and replace. IBL is an attempt at a revised synthesis which, in terms of both its content and synthesising function, is comparable to the pragmatic peacebuilding texts such as MSW and R2P. The discursive incorporation which they represent constitutes a further realignment of neo-liberal temporal and spatial conceptions. The attempt to rescue and reform peacebuilding - rather than comprehend it as a functional 'myth' and/or thoroughly reconceptualise it - characterises the moderate criticism of many pragmatists who work directly with the International Community and are orientated towards policy prescription. Such texts obfuscate the distinction between humanitarian and military interventions which was at one time inviolable in the International Community. Since Kosovo, many liberal public intellectuals have come to the defence of such mergers, for example Ulrich Beck's notion of 'militaristic humanitarianism'. ${ }^{123}$ Michael Ignatieff, for example, whilst criticising the failure of the interventionists to take imperial responsibility, defends the use of military intervention and 'imperial policing' in explicit advocacy for what he calls 'Empire lite' - another idea which relies heavily on the inter-textual connections of justice and order. He argues:

Imperialism used to be the white man's burden. This gave it a bad reputation. But imperialism doesn't stop being necessary just because it becomes politically incorrect. Nations sometimes fail, and when they do outside help - imperial power can get them back on their feet. Nation-building is the kind of imperialism you get in an human rights era, a time when great powers believe simultaneously in the right of small nations to govern themselves and their own right to rule the world. ${ }^{124}$

Such interpellation of discourses, where military-led statebuilding comes to be portrayed as humanitarian, and humanitarianism as necessarily requiring military intervention, illustrates the intense inter-textuality of peacebuilding. It also indicates the hegemonic position of the International Community as a legitimate agent of diverse acts of intervention. By 2008, five years into the Iraq war and 'nation-building' venture, 'peacebuilding' lives on but its essential quality is as hard to distinguish as ever. It retains a tri-partite character, being at times one peacebuilding and at times three (see figure 2). Through such discursive practices of incorporation, the International Community battles to re-present the liberal peace.

\footnotetext{
${ }^{120}$ Paris quotes extensively and affirmatively from Huntingdon, Political Development, whilst raising concerns about his enthusiasm for transition via military government. Paris, At War's End, 185-187.

${ }^{121}$ Roland Paris, 'Bringing the Leviathan Back In: Classical Versus Contemporary Studies of the Liberal Peace', International Studies Review 8, no.3 (2006), 425.

${ }^{122}$ Paris, At War's End, 179-211.

${ }^{123}$ Slavoj Žižek, The Fragile Absolute, (London: Verso, 2000), 56-57.

${ }^{124}$ Michael Ignatieff, 'Nation-Building Lite,' New York Times Magazine, 28 July 2002, 26.
} 
Fig.2: Summary of discursive development of peacebuilding, 1989-2006

\begin{tabular}{|c|c|c|c|c|c|c|c|c|}
\hline $\begin{array}{l}\text { Discourse of } \\
\text { peacebuildin } \\
\mathbf{g}\end{array}$ & $\begin{array}{l}\text { Spatial } \\
\text { ideal-other }\end{array}$ & $\begin{array}{l}\text { Ethical } \\
\text { ideal-other }\end{array}$ & $\begin{array}{l}\text { Temporal } \\
\text { ideal-other }\end{array}$ & $\begin{array}{l}\text { Discursive } \\
\text { Antecedents }\end{array}$ & $\begin{array}{l}\text { Practical } \\
\text { antecedents }\end{array}$ & $\begin{array}{l}\text { High } \\
\text { point(s) }\end{array}$ & $\begin{array}{l}\text { Example } \\
\text { texts/author } \\
\mathrm{s}\end{array}$ & Low points \\
\hline $\begin{array}{l}\text { Democratic } \\
\text { Peacebuilding } \\
\text { a.k.a. } \\
\text { 'post-conflict } \\
\text { peacebuilding' }\end{array}$ & $\begin{array}{l}\text { Formal } \\
\text { institutions: } \\
\text { 'structures which } \\
\text { will tend to } \\
\text { strengthen and } \\
\text { solidify peace' } \\
\text { (AfP, 1992) }\end{array}$ & $\begin{array}{l}\text { LIBERAL- } \\
\text { DEMOCRACY: } \\
\text { Human rights, } \\
\text { Constitutionali } \\
\text { sm, } \\
\text { Private } \\
\text { property }\end{array}$ & $\begin{array}{l}\text { Short-term } \\
\text { post-conflict } \\
\text { progress }\end{array}$ & $\begin{array}{l}\text { Wilsonian/Idealist } \\
\text { writing (1920s \& } \\
\text { 30s); } \\
\text { Democratisation } \\
\text { lit (since 1970s) } \\
\text { Democratic } \\
\text { peace lit in IR }\end{array}$ & $\begin{array}{l}1989 \text { and end } \\
\text { of the Cold } \\
\text { War }\end{array}$ & Early-1990s & AfP (1992) & $\begin{array}{l}\text { Somalia } \\
\text { (1992-1993), } \\
\text { Rwanda } \\
(1994), \\
\text { Bosnia (1992- } \\
\text { 1995). }\end{array}$ \\
\hline $\begin{array}{l}\text { Civil Society } \\
\text { a.k.a. } \\
\text { 'Bottom-up } \\
\text { peacebuilding' } \\
\text {; 'grassroots } \\
\text { peacebuilding' }\end{array}$ & $\begin{array}{l}\text { Communities, } \\
\text { grassroots, } \\
\text { (global) civil } \\
\text { society, bottom-up } \\
\text { participation }\end{array}$ & $\begin{array}{l}\text { JUSTICE: } \\
\text { Universality, } \\
\text { neutrality and } \\
\text { impartiality } \\
\text { (humanitariani } \\
\text { sm) }\end{array}$ & $\begin{array}{l}\text { Pre-, during } \\
\text { and post- } \\
\text { conflict } \\
\text { progress }\end{array}$ & $\begin{array}{l}\text { Constitutions and } \\
\text { programmes of } \\
\text { humanitarian aid } \\
\text { agencies; } \\
\text { religious non- } \\
\text { violence } \\
\text { literature }\end{array}$ & $\begin{array}{l}\text { Failures of } \\
\text { Rwanda, } \\
\text { Bosnia and } \\
\text { others in } \\
\text { early-mid } \\
\text { 1990s }\end{array}$ & $\begin{array}{l}\text { Mid- to Late- } \\
\text { 1990s }\end{array}$ & $\begin{array}{l}\text { Carnegie } \\
(1997) ; \\
\text { Lederach } \\
\text { (1997); } \\
\text { Anderson } \\
(1999)\end{array}$ & $\begin{array}{l}\text { Sept. 11, } \\
2001, \text { attacks } \\
\text { and rising } \\
\text { concern over } \\
\text { terrorism }\end{array}$ \\
\hline $\begin{array}{l}\text { State-building } \\
\text { a.k.a. } \\
\text { 'nation- } \\
\text { building'; } \\
\text { 'stabilisation' }\end{array}$ & $\begin{array}{l}\text { Sovereign state, } \\
\text { top-down } \\
\text { governance }\end{array}$ & $\begin{array}{l}\text { ORDER: } \\
\text { Government, } \\
\text { Rule of Law, } \\
\text { Anti-Terrorism }\end{array}$ & $\begin{array}{l}\text { Long-term } \\
\text { post-conflict } \\
\text { progress } \\
\text { (under } \\
\text { transitional } \\
\text { administratio } \\
\text { n) }\end{array}$ & $\begin{array}{l}\text { Political realist } \\
\text { writing; } \\
\text { Huntington, } \\
\text { (1968), } \\
\text { modernisation; } \\
\text { state failure } \\
\text { literature (early- } \\
\text { 1990s). } \\
\end{array}$ & $\begin{array}{l}\text { Kosovo } \\
\text { (1999), Sept. } \\
11,2001, \\
\text { attacks and } \\
\text { intervention in } \\
\text { Afghanistan } \\
\text { (2001) }\end{array}$ & $\begin{array}{l}\text { Circa. 2002- } \\
2005 \\
\text { esp. Iraq } \\
(2003-2004)\end{array}$ & $\begin{array}{l}\text { US National } \\
\text { Security } \\
\text { Strategy } \\
(2002) ; \\
\text { Fukuyama } \\
(2004)\end{array}$ & $\begin{array}{l}\text { Iraq (since } \\
2005) ; \\
\text { Afghanistan } \\
\text { (since 2004) }\end{array}$ \\
\hline $\begin{array}{l}\text { Meta- } \\
\text { discourse of } \\
\text { pragmatic } \\
\text { peacebuilding }\end{array}$ & $\begin{array}{l}\text { Inter-textually- } \\
\text { produced: top- } \\
\text { down and bottom- } \\
\text { up, shift towards } \\
\text { privileging of state }\end{array}$ & $\begin{array}{l}\text { Inter-textually- } \\
\text { produced: } \\
\text { neoliberal, } \\
\text { technical- } \\
\text { rational }\end{array}$ & $\begin{array}{l}\text { Inter- } \\
\text { textually- } \\
\text { produced: } \\
\text { shift to } \\
\text { longer-term }\end{array}$ & $\begin{array}{l}\text { Democratic, civil } \\
\text { society, and } \\
\text { statebuilding } \\
\text { discourses }\end{array}$ & $\begin{array}{l}\text { Perceived } \\
\text { failures of } \\
\text { democratic, } \\
\text { civil society, } \\
\text { and }\end{array}$ & $\begin{array}{l}\text { At moments } \\
\text { of increased } \\
\text { inter- } \\
\text { textuality } \\
\text { between }\end{array}$ & $\begin{array}{l}\text { Supplement to } \\
\text { AfP (1995); } \\
\text { Brahimi Report } \\
\text { (2000); } \\
\text { R2P (2001); }\end{array}$ & $\begin{array}{l}\text { At moments } \\
\text { of the } \\
\text { domination of } \\
\text { one discourse } \\
\text { and reduced }\end{array}$ \\
\hline
\end{tabular}




\begin{tabular}{|l|l|l|l|l|l|l|}
$\begin{array}{l}\text { sovereignty in } \\
\text { recent years }\end{array}$ & $\begin{array}{l}\text { (denial of } \\
\text { contestedness } \\
\text { of } \\
\text { standpoints) }\end{array}$ & $\begin{array}{l}\text { since early } \\
\text { 1990s }\end{array}$ & & $\begin{array}{l}\text { statebuilding } \\
\text { practices }\end{array}$ & $\begin{array}{l}\text { discourses: } \\
\text { c. 1995; } \\
\text { c. 2000; } \\
\text { c. 2004-? }\end{array}$ & $\begin{array}{l}\text { Paris (2004); } \\
\text { MSW (2004); }\end{array}$ \\
\hline
\end{tabular}




\section{Conclusions and Implications}

This paper has assessed the dynamics of the 'liberal peace' in terms of the shift from peace to peacebuilding and on, within the discursive space of peacebuilding, to statebuilding. It charted the development of peacebuilding not as consistent, 'experience-led' or 'evidencebased' but as a highly political process of inter-textual relations and incorporative practices of the International Community. Neo-liberal, international peacebuilding's very durability is a product of the dynamism of its discursive environment.

This paper makes three conclusions and three propositions about regarding the tripartite peacebuilding of the post-Cold War era. The first conclusion is that peacebuilding is trinitarian and in conflict. That is, it takes place in a discursive environment of conflict, of competing inscriptions. Despite the shift from 'peace' to 'peacebuilding', Banks' concepts of peace (conflict management; order; justice) have been reconstituted in peacebuilding through variations upon the theme in the form of civil society (humanitarian) and statebuilding discourses. Second, peacebuilding becomes, in moments, unitarian and homogenous. That is, these contentions are frequently elided in a single meta-discourse. The conflict between three basic discourses provides the dynamism and the parameters by which peacebuilding as a 'pragmatic' concept is regenerated. The contrasts between them indicate the essentially contested and shifting nature of pragmatic peacebuilding, while their conciliation under grand narratives exhibits the nature of hegemonic incorporation. Thirdly, peacebuilding is not essentially liberal. Nor, despite its tripartite structure, is it properly plural. In this sense it is neoliberal. There are well-defined limits on the extent to which peacebuilding can evolve in the international discursive environment. But this is not to say it is entirely technical. Rather it is a form of governmentality where ethical, spatial and temporal shift markers inconsistently under a hybrid liberal-conservative-humanitarian mode of hegemonic governance.

These three conclusions about the discursive environment of peacebuilding give rise to three propositions about the changing nature of world order since 1989. In each of the subsequent three proposals 'contemporary world order' could be substituted for 'peacebuilding' to convey this meaning. First, peacebuilding is practically imperial. In its focus on ethnopolitical conflict, peacebuilding justifies a degree of international intervention within 'failed states' which has been formally absent since the decline of colonialism after the Second World War. Whether or not we identify the contemporary international order as that of Empire, we must acknowledge the imperial practices of contemporary international peacebuilding. Secondly, peacebuilding necessarily fails to live up to its ideals. The very nature of peacebuilding (as a discourse which idealises and attempts to 'self-legitimate' the International Community) institutionalises a gaping chasm between what is represented and what is practiced. Its 'goals' are self-images which must be simulated in the other. As Richmond argues, it is a 'virtual peace' in that it is 'mainly visible to those observing from the outside of the conflict zone in the liberal international community rather than those upon whom this peace is being visited'. ${ }^{125}$ Finally, and in keeping with the first proposition, peacebuilding represents the mutual inclusiveness of the idea of peace and the practice of war. Earlier invocations of the concept of peace - as an orderly balance of power (a negative peace) or an inclusive system of social justice (a positive peace) - gave rise to the idea that peace and war were mutually exclusive. This mutual exclusivity has been questioned from Tacitus to George W. Bush. ${ }^{126}$ Today, the

${ }^{125}$ Richmond, The Transformation of Peace, 185.

${ }^{126}$ Tacitus wrote in reporting the speech of Calgacus, a leader of the Britons: 'To robbery, 
process of international peacebuilding takes place 'over generations' and its endpoint is rarely if ever defined. Peacebuilding provides a widely accepted justification for the permanence of war or very high levels of organised violence in post-conflict spaces. Under peacebuilding war and 'peace' are always with us.

John Heathershaw is Lecturer in International Relations in the Department of Politics at the University of Exeter

butchery, and rapine they give the lying name of 'government'; they create a desolation and call it peace'. See, Tacitus, The Agricola and the Germania, (Harmondsworth, Middlesex: Penguin, 1970), 81. George W. Bush named the United States as a 'peaceful people' when embarking upon war with Iraq. 